\title{
MACAM-MACAM SISTEM EKONOMI DAN KEMEROSOTAN SISTEM EKONOMI SYARIAH (Ekonomi Syariah Di Dalam Dunia Global)
}

\author{
Amirudin \\ Fakultas Hukum Keluarga IAIN Madura, Jl. Panglegur Km. 04 Pamekasan, \\ email: amirudin@gmail.com
}

AH. Kusairi

Fakultas Syariah IAIN Madura, Jl. Raya Panglegur Km. 4 Pamekasan, email:ah.kusairi@gmail.com

\begin{abstract}
Abstrak:
Ekonomi syariah adalah suatu cabang ilmu pengetahuan yang merupakan yang berupaya untuk memandang penting, mengalisis, dan akhirnya juga menyelesaikan permasalahan-permasalahan ekonomi dengan cara yang islami, yaaitu atas dasar ajaran agama islam yaitu al-quran dan sunnah nabi, ekonomi syariah memiliki dua hal pokok yang menjadi landasan hukum system ekonomi syariah yaitu al-quran dan sunnah rasulullah saw, hukum-hukum diambil dari landasan pokok tersebut secara prinsip dan konsep tidak dapat berubah kapanpun dan dimanapun. Ekonomi syariah selaran dengan tujuan syariat islam, yaitu maqashid syariah hal tersebut bertujuan untuk mencapai kebahagian duania dan akhirat melalui suatu tatana kehibupan yang terhormat. Tujuan tersebut yang ingin dicapai oleh ekonomi syariah meliputi aspek kecil maupun besar. Ada tiga sasaran untuk menunjukan bahwa islam diturunkan secara rahmat bagi semua manusia, satu penyucian jiwa agat semua muslim bisa menjadi salah satu sumber kebaikan bagi lingkungan dan masyarakat, dua tegaknya keadilan dalam bermasyarakat. Keadilan yang diamaksud meliputi aspek kehidupan dibidang muamalah dan hukum. Tiga tercapainya maslaha merupakan tujuan utama. (Islamic economics is a branch of science which is an attempt to look at the importance, analyze, and finally also solve economic problems in an Islamic way, that is, on the basis of the teachings of Islam namely the Qur'an and the Sunnah of the Prophet, Islamic economics has two main points which became the legal basis of the Islamic economic
\end{abstract}


system, namely the Koran and the Sunnah of Rasulullah SAW, the laws taken from this basic foundation in principle and concept cannot change anytime and anywhere. Islamic economics in harmony with the aim of Islamic law, namely maqashid sharia it aims to achieve happiness in Lithuania and the Hereafter through an honorable order. These objectives to be achieved by Islamic economics include small and large aspects. There are three targets to show that Islam is revealed in a grace to all humans, one purification of the soul of all Muslims can be a source of goodness for the environment and society, two upholds justice in society. The intended justice covers aspects of life in muamalah and law. The achievement of maslaha is the main goal).

\section{Kata Kunci:}

Macam-Macam, Ekonomi Syariah, Perbedaannya.

\section{Pendahuluan}

Kegagalan system ekonomi sosisal dan sistem ekonomi kapitalis memunculkan pemikiran baru mengenai system perekonomian terutama di negara islam yaitu system ekonomi syariah. Negara-negara yang mayoritas muslim penduduknya mencoba untuk menerapkan sebuah system baru, yaitu system ekonomi yang berlandaskan pada al-quran dan hadist yakni ekonomi syariah, sitem yang mampu dan terbukti berhasim membawa kaum muslimin di masa rasulullah dan meningkatkan perekonomian di jazerah arab. Dari pemikiran tersebut, pada saat ini sedang dikembangkan system ekonomi syariah dan ekonomi syariah di banyak negara muslim termasuk negara Indonesia. Sistem ekonomi syariah dan ekonomi syariah adalah perwujudan dari pradikma islam. Pengembangan sisem ekonomi syariah dan ekonomi syariah bukan lagi untuk mengalahkan system ekonomi sosialis dan system ekonomi kapitalis namun lebiih untuk menemukan system ekonomi yang mempunyai kelebihan dari system ekonomi yang ada islam juga diturunkan keduania ini untu mengatur keg=hidupan manusia dalam 
Macam-Macam Sistem Ekonomi

dan Kemerosotan Sistem Ekonomi Syariah

(ekonomi syariah di dalam dunia global)

rangka terciptanya ketentraman hidup dan kebahagian manusia di dunia juga di akhirat.

Sebagai ekonomi tertinggi. manusia yang dimaksud saat ini tidak sebatas ummat muslim, tetapi seluruh ummat manusia. Ketentraman hidup juga bukan hanya sebatas dapat memenuhu kebutuhan hidup secara melimpah ruah di dunia fana, tetapi juga dapat memenuhi ketentraman jiwa untuk bekal di akhirat nanti.

\section{Metodelogi penelitian}

Penelitian ini menggunakan pendekatan kualitatif (qualitative approach). Peneliti melihat fenomena yang berkembang sebagai satu kesatuan yang utuh, yang tidak terikat dengan satu variable atau hipotesis tertentu. Pendekatan ini akan memudahkan peneliti dalam menemukan persoalan-persoalan ganda, mendekatkan diri peneliti dengan subyek yang diteliti, serta lebih peka dan lebih dapat menyesuaikan diri terhadap pengaruh fenomena yang ada di lapangan.

\section{Kerangka teoritik}

Secara teoritik, hukum-hukum agama (syari`at Islam) yang hendak diberlakukan dalam sistem hukum negara sesungguhnya memiliki hubungan dengan politik karena syari at Islam merupakan hukum agama yang hendak diberlakukan oleh negara dan negara merupakan institusi politik yang berwenang membentuk hukum negara. Itulah sebabnya muncul perdebatan dalam konteks hubungan hukum dan politik; apakah hukum yang mempengaruhi politik atau sebaliknya politik yang mempengaruhi hukum.

\section{Macam-Macam Sistem Ekonomi dan Perbedaannya}

Kalau kita membahas macam-macam sistem ekonomi di dunia tentunya sangat banyak namun disisni penulis hanya akan memberikan beberapa gambaran saja yang sudah tidak asing lagi di dengar bahkan juga menjadikan sebagai sistem kita dalam kehidupan sehari-hari. Namun dalam perbedaan kami sebagai penulis tidak terlalu gamblang menjelaskannya. 
Amirudin

\section{a. Sistem ekonomi libral atau kapitalis}

Sistem ekonomi liberal kapitalis adalah sebuah sistem ekonomi yang aset-asetnya tersebut produktif dan faktor-faktor produksinya sebagian besar dimiliki oleh sektor individu/swasta. Sementara tujuan utama kegiatan tersebut produksinya adalah untuk menjual dengan tujuan memperoleh laba. Sistem perekonomian atau tata ekonomi liberal atau kapitalis merupakan sistem perekonomian yang telah memberikan kebebasan kepada setiap orang atau individu untuk melaksanakan kegiatan perekonomian seperti memproduksi barang, menjual barang, menyalurkan barang dan lain sebagainya.

Dalam perekonomian liberal atau kapitalis setiap warga dapat mengatur nasibnya sendiri sesuai dengan kemampuannya yang di miliki sendiri. Semua orang bebas bersaing dalam bisnis tersebut untuk memperoleh laba sebesar- besarnya dan bebas melakukan kompetisi untuk memenangkan persaingan bebas secara sehat. Ciriciri dari sistem ekonomi liberal kapitalis antara lain ${ }^{1}$ :

- Masyarakat diberi kebebasan secara lansung dalam memiliki sumber-sumber produksinya.

- Pemerintah dalam hal initidak ikut campur tangan secara langsung dalam kegiatan ekonomi.

- Masyarakat terbagi menjadi dua golongan, yaitu sebagai golongan pemilik sumber daya produksi dan masyarakat sebagai pekerja (buruh).

- Timbul persaingan dalam masyarakat tersebut, terutama dalam hal mencari keuntungan.

- Kegiatan selalu mempertimbangkan oleh keadaan pasar.

- Pasar merupakan dasar setiap tindakan ekonomi.

- Biasanya barang-barang yang produksi itu dihasilkan bermutu tinggi.

Perbedaan sistem ekonomi Islam dan sistem ekonomi kapitalis tidak haya pada hal-hal yang bersifat aplikatif. Namun mulai dari fasafahnya sudah berbeda. Di atas falsafah yang berbeda ini dibangun tujuan, norma dan prinsip-prinsip yang berbeda. Hal ini karena

\footnotetext{
${ }^{1}$ Winardi, 1987 Pengantar Ekonomi Moneter, Buku-1, Bandung: Tarsito.
} 
Macam-Macam Sistem Ekonomi

dan Kemerosotan Sistem Ekonomi Syariah

(ekonomi syariah di dalam dunia global)

keyakinan seseorang mempengaruhi cara pandang dalam membentuk kepribadian, perilaku, gaya hidup, dan selera manusia. Dalam konteks yang lebih luas, keyakinan juga mempengaruhi sikap terhadap orang lain, sumber daya, dan lingkungan. Dalam sistem kapitalis, Tuhan dipensiunkan (retired God). Hal ini direfleksikan dalam konsep "laissez faire" dan "invisible hand". Dari falsafah ini kita bisa melihat tujuan ekonomi kapitalis hanya sekadar pertumbuhan ekonomi. Asumsinya dengan pertumbuhan ekonomi setiap individu dapat melakukan kegiatan ekonomi demi tercapainya kepuasan individu. Begitu pula dengan norma-norma ekonomi. Karena peran Tuhan sudah ditiadakan, semua hal diserahkan kepada individu. Akibatnya dalam sistem kapitalis kepemilikian individu menjadi absolut. Norma-norma yang dibangun berdasarkan pada individualisme dan utilitarianisme. Setiap barang dianggap baik selama bernilai jual. Tidak ada batasan ataupun norma yang jelas, baik dan buruk diserahkan kepada individu masing-masing. Dari sinilah kerusakan berawal. Terjadi kedzaliman terhadap sesama manusia, ketimpangan ekonomi dan sosial, perusakan alam, dan sebagainya. Semuanya terjadi demi meraih kepuasan individu tanpa dibatasi oleh norma-norma agama. Falsafah ekonimi Islam secara umum dapat dilihat dari surat al-Muthaffifin ayat 1 sampai 6. Allah berfirman: 1) Kecelakaan besarlah bagi orang-orang yang curang. 2) (Yaitu) orang-orang yang apabila menerima takaran dari orang lain mereka minta dipenuhi. 3) Dan apabila mereka menakar atau menimbang untuk orang lain, mereka mengurangi. 4) Tidaklah orangorang itu menyangka, bahwa Sesungguhnya mereka akan dibangkitkan. 5) Pada suatu hari yang besar. 6) (Yaitu) hari (ketika) manusia berdiri untuk menghadap sang maha kuasa semesta alam Tuhan. $^{2}$

Ayat di atas menunjukkan adanya hubungan yang erat antara agama, keyakinan kepada Allah, keyakinan kepada hari Akhir, perilaku ekonomi, dan sistem ekonomi. Karena itu, dari sisi tujuannya, ekonomi Islam bertujuan mencapai kesejahteraan manusia dalam rangka ibadah kepada Allah. Umat Islam juga meyakini Allah yang menciptakan bumi beserta isinya. Karena itu, pemilik hakiki bumi dan seisinya adalah Allah. Manusia hanya diberi hak pakai

\footnotetext{
${ }^{2}$ https://www.eramuslim.com
} 


\section{Amirudin}

(sebagai amanah). Karena itu, manusia memiliki kewajiban untuk mengelolanya sesuai dengan otorisasi Syara' (berdasarkan normanorma Islam). Hal ini karena apapun yang dilakukan manusia di dunia akan dimintai pertanggungjawabannya oleh Allah Swt. Dampak positifnya adalah manusia akan senantiasa hati-hati dalam bertindak dan akan selalu memperhatikan rambu-rambu yang telah ditetapkan Allah dan Rasul-Nya.

\section{b. Sistem ekonomi sosial}

Seperti yang dijelaskan di Dumairy, sistem ekonomi sosialis adalah kebalikan dari sistem ekonomi kapitalis. Bagi kalangan sosialis, pasar justru adalah sebuah sistem yang harus dikendalikan melalui sebuah perencanaan terpusat. Adanya berbagai distorsi dalam mekanisme pasar tersebut menyebabkannya tidak mungkin bekerja secara efisien dan efektif, oleh karena itu pemerintah atau Negara harus turut ikut aktif bermain dalam perekonomian tersebut. Satu hal yang lebih penting untuk dicatat berkenaan dengan system ekonomi sosialis tersebut adalah bahwa sistem ini bukanlah sistem ekonomi yang tidak memandang penting peranan kapital.

Sistem ekonomi sosialis dapat dibagi dalam dua subsistem, yakni sistem ekonomi sosialis dari Marxis, dan sistem ekonomi sosialis demokrat. Sistem ekonomi sosialis dari Marxis disebut juga sistem ekonomi komando dimana seluruh unit ekonomi, baik sebagai produsen, konsumen maupun pekerja, tidak diperkenankan untuk mengambil keputusan secara sendiri-sendiri yang menyimpang dari komando ototritas tetinggi, yakni partai. Dalam sistem ekonomi sosialis ini, seperti yang dianut dulu oleh Uni Soviet dan Negaranegara komunis di Eropa Timur, atau mmilih di terapkan hingga sekarang di Korea Utara dan mungkin hingga tingkat tertentu di Cuba, partai menentukan secara rinci arah serta sasaran yang harus dicapai dan yang harus dilaksanakan oleh setiap unit ekonomi dalam pengadaan baik dalam pengadaan baik barang-barang untuk sosial (social goods) maupun untuk pribadi (private goods). Unit-unit ekonomi sepenuhnya tunduk pada komando dari otoritas tertinggi tanpa ikut campur sedikitpun juga didalam proses pengambilan keputusan dalam menentukan arah kebijakan dan sasaran yang akan di capai. Dalam perkataan lain, dalam sistem ekonomi sosialis dari 


\section{Macam-Macam Sistem Ekonomi dan Kemerosotan Sistem Ekonomi Syariah (ekonomi syariah di dalam dunia global)}

Marxis ruangan gerak bagi para pelaku-pelaku ekonomi untuk mengambil inisiatif sendiri dapat dikatakan tidak sama sekali. Dalam sistem ekonomi sosialis demokrat, seperi yang dianut oleh banyak Negara di Eropa Besar (terutama Jerman), dapat dikatakan bahwa kekuasaan otoritas tertinggi jauh berkurang. Dalam sistem ini, di satu pihak, ada kebebasan individu sperti dalam sistem ekonomi kapitalis, misalnya produsen bebas memilih jenis dan beberapa banyak produksi yang akan dibuat; konsumen bebas memilih barang mana yang dikehendaki; dan pekerja bebas menentukan jenis peerjaan apa saja yang diinginkannya. Namun, dipihak lain, berbeda dngan sistem eonomi kapitalis, dalam sistem ekonomi kapitalis sosialisme demokrat, peran pemerintah lebih besar. Misalnya di Negara-negara sosialis demokrat di Eropa Barat ada ketentuan ketentuan mengenai upah minimum dan penetapanan harga minimum atau maksimum, serta ada kebijaksanaan perlindungan usaha konsumen, dan pekerja. $^{3}$

Landasan ilmiah dari sistem ini adalah kombinasi antara prinsip-prinsip kebebasan individu dengan kemerataan sosial, jadi bukan pasar bebas yang liberal dan juga bukan paham ekonomi monetaris yang tidak menghendaki investasi pemerintah dalam bentu apapun. Menurut Mubyarto (2000), berdasarkan pengalaman di Jerman, ada 6 kriteria ekonomi sosialisme demokrat atau sistem ekonomi pasar social (SEPS), yaitu sebagai berikut.

- Ada kebebasan individu dan sekaligus kebijaksanaan perlindungan usaha. Persaingan di antara perusahaanperusahaan kecil maupun menengah harus dikembangkan.

- Prinsip-prinsip kemeerataan social menjdi tekad warga masyarakat.

- Kebijaksanaan siklus bisnis dan kaitannya dengan pertumbuhan ekonomi.

\footnotetext{
${ }^{3}$ Tulus T.H Tambunan, 2009. Perekonomian Indonesia. Bogor: Galia Indonesia
} 
Amirudin

- Kebijaksanaan pertumbuhan menciptakan kerangka hukum dan prasarana (sosial) yang terkait dengan pembangunan ekonomi.

- Kebijaksanaan structural.

- Konformitas pasar dan persaingan.

\section{c. Sistem ekonomi campuran}

Sistem ekonomi campuran adalah sistem yang mengandung beberapa elemen dari sistem ekonomi kapitalis dan sistem ekonomi sosialis. Seperti telah dikatakan sebelumnya, sekarang ini tidak ada satupun (terkecuali di Korea Utara) Negara yang menerapkan sistem ekonomi sosialis atau kapitalis 100 \%. Jadi, sistem ini merupakan "campuran" antara kedua sistem ekonomi tersebut diatas, dengan berbagai variansi kadar dominasinya.

Sanusi menjelaskan bahwa sistem ekonomi campuran sebagai berikut: Dalam sistem ekonomi campuran dimana kekuasaan dan kebebasan berjalan secara kebersamaan walau dalam kadar yang berbeda-beda. Ada sistem ekonomi campuran yang mendekati sistm kapitalis atau liberalis karena kadar kebasan yang relatif besar atau presentase dari sistem kapitalisnya sangat besar. Adapula sistem ekonomi campuran yang mendekati ekonomi soosialis dimana peran kekuasaan pemerintah relative besar terutama dalam menjalankan berbagai kebijakan ekonomi, moneter atau fiscal dan lain-lain. Di dalam sistem ekonomi campuran adanya sebuah campur tangan pemerintahterutama untuk mengendalikan kehidupan atau pertumbuhan ekonomi, mencegah adanya konsentrasi yang terlalu besar di tangan satu orang atau kelompok swasta, juga untuk melakukan stabilisasi perekonomian, mengatur tata tertib serta membantu golongan ekonomi lemah. ${ }^{4}$

Sistem ekonomi campuran merupakan perpaduan antara sistem kapitalis dan sistem sosialis. Perpaduan ini mengambil garis tengah antara kebebasan dan pengendalian. Jadi, dapat diartikan sebagai jalan tengah antara peran mutlak negara dan peran menonjol

\footnotetext{
${ }^{4}$ http:/ / putriagustia.blogspot.com/2011/02/ sistem-ekonomi-menurut-paraahli.html
} 


$$
\begin{array}{r}
\text { Macam-Macam Sistem Ekonomi } \\
\text { dan Kemerosotan Sistem Ekonomi Syariah } \\
\text { (ekonomi syariah di dalam dunia global) }
\end{array}
$$

individu. Jalan tengah ini disesuaikan dengan keadaan saat perpaduan itu terjadi sehingga peran situasi dan lingkungan sangat memberi warna pada sistem campuran tersebut. Sistem ekonomi campuran banyak dianut oleh negara berkembang. Ciri-Ciri Sistem Ekonomi Campuran

- Kegiatan ekonomi dilakukan oleh pihak pemerintah dan pihak swasta.

- Transaksi ekonomi terjadi di pasar dan ada campur tangan dari pemerintah.

- Ada persaingan serta masih ada kontrol dari pemerintah.

- Lebih mementingkan kepentingan umum daripada kepentingan golongan.

- Adanya kebebasan berusaha dapat mendorong kreativitas individu sesuai dengan kemampuannya.

- Sumber-sumber daya yang vital dikuasai oleh pemerintah.

- Pemerintah menyusun peraturan, perencanaan, dan menetapkan kebijaksanaan-kebijaksanaan di bidang ekonomi.

- Swasta diberi kebebasan di bidang-bidang ekonomi dalam batas kebijaksanaan ekonomi yang ditetapkan pemerintah.

- Hak milik swasta atas alat produksi diakui, asalkan penggunaannya tidak merugikan kepentingan umum.

- . Jenis dan jumlah barang diproduksi ditentukan oleh mekanisme pasar. 


\section{Amirudin}

Berikut table sederhannya

\begin{tabular}{|c|c|}
\hline KONSEP ISLAM & KONSEP KONVENSIONAL \\
\hline Uang tidak identik & Uang seringkali diidentikkan \\
dengan modal. & dengan modal. \\
Uang adalah public goods. & Uang (modal) adalah private \\
Modal adalah private & goods. \\
goods. & Uang (modal) adalah flow \\
Uang adalah flow concept. & concept bagi fisher. \\
Modal sebagai stock & Uang (modal) adalah sebuah \\
concept. & stock concept bagi Cambridge \\
& school \\
& \\
\hline
\end{tabular}

\section{Pengertian Uang}

Uang yang kita kenal saat sekarang adalah hasil perkembangan yang sangat panjang, sepanjang peradaban manusia. Ketika manusia belum mengenal pertukaran, setiap orang berusaha memenuhi kebutuhan manusia dalam kehidupan sehariharinya dengan usaha sendiri. Berburu jika lapar datang. Membuat pakaian sendiri dari bahan-bahan yang sangat sederhana. Mencari buah-buahan untuk dikonsumsi sendiri. Singkatnya, yang diperoleh itulah yang dimanfaatkan untuk memenuhi setiap kebutuhannya.

Akan tetapi kemudian yang dibuat sendiri tidak cukup untuk memenuhi segala kebutuhan. Lalu dicarilah barang-barang lain yang tidak dapat dihasilkan oleh mereka sendiri, dari orang lain yang bersedia untuk menukarkan barang miliknya dalam sistem barter. Namun dalam sistem ini ada batasnya, sehingga muncullah keinginan untuk memakai benda tertentu sebagai alat tukar. Benda itu harus diterima secara umum (generally accepted), bernilai tinggi (sukar diperoleh atau memiliki nilai magis dan mistik), atau benda kebutuhan primer seperti garam. Benda yang sangat dianggap indah dan bernilai seperti kerang juga pernah dijadikan sebagai alat tukar sebelum manusia menemukan uang logam. 
Macam-Macam Sistem Ekonomi

dan Kemerosotan Sistem Ekonomi Syariah

(ekonomi syariah di dalam dunia global)

Meskipun alat tukar tersebut sudah ada, tapi tetap muncul kesulitan dalam sistem pertukaran tersebut. Antara lain karena benda-benda yang dijadikan alat tukar belum mempunyai pecahan yang sederhana sehingga penentuan nilai uang, penyimpanan dan pengangkutan sulit dilakukan. Timbul pula kesulitan akibat kurangnya daya tahan benda-benda itu karena mudah hancur atau tidak tahan lama. Kemudian muncul uang logam. Logam dipilih sebagai alat tukar karena memiliki nilai tinggi sehingga digemari umum, tahan lama dan tidak mudah rusak, tidak mudah dipecah tanpa mengurangi nilai, dan mudah dipindah-pindahkan. Logam sebagai alat tukar karena memenuhi syarat-syarat tersebut adalah emas dan perak. Uang logam emas dan perak juga disebut uang penuh (full bodied money). Artinya, nilai intrinsik (nilai bahan) uang sama dengan nilai nominalnya (nilai yang tercantum pada mata uang tersebut). Saat itu, setiap orang berhak menempa uang, melebur, menjual atau memakainya, dan mempunyai hak tidak terbatas dalam menyimpan uang logam.

Seiring perekonomian berputar, tukar-menukar dengan uang logam menigkat. Timbul anggapan stok logam (emas dan perak) akan terbatas bila trasaksi meningkat terus. Apalagi jika nanti transaksinya dalam jumlah besar. Diciptakanlah uang kertas. Mula-mula uang kertas yang beredar merupakan bukti-bukti kepemilikan emas dan perak sebagai alat/perantara untuk bertransaksi. Dengan kata lain, uang kertas yang beredar saat itu merupakan uang yang dijamin $100 \%$ dengan emas atau perak yang disimpan di gudang pandai emas atau perak dan sewaktu-waktu uang kertas tersebut dapat ditukarkan penuh dengan jaminannya (emas atau perak). Selanjutnya masyarakat tidak lagi menggunakan emas (secara langsung) sebagai alat pertukaran, dan menjadikan "kertas-bukti" tersebut sebagai alat tukar.

Uang adalah alat tukar atau instrument yang cukup penting dalam proses transaksi ekonomi. Uang diciptakan dalam perekonomian dengan tujuan untuk melancarkan kegiatan tukar menukar dan perdagangan. Maka uang didefinisikan sebagai bendabenda yang disetujui oleh masyarakat sebagai alat perantaraan untuk mengadakan tukar menukar atau perdagangan. 


\section{Amirudin}

Secara sederhana uang didefenisikan sebagai segala sesuatu yang dipergunakan sebagai alat bantu dalam pertukaran. Secara hukum, uang adalah sesuatu yang dirumuskan oleh undang-undang sebagai uang. Jadi segala sesuatu dapat diterima sebagai uang jika ada aturan atau hukum yang menunjukkan bahwa sesuatu itu dapat digunakan sebagai alat tukar.

Uang dalam ilmu ekonomi tradisional didefinisikan sebagai setiap alat tukar yang dapat diterima secara umum. Alat tukar itu dapat berupa benda apapun yang dapat diterima oleh setiap orang di masyarakat dalam proses pertukaran barang dan jasa. Dalam ilmu ekonomi modern, uang didefinisikan sebagai sesuatu yang tersedia dan secara umum diterima sebagai alat pembayaran bagi pembelian barang-barang dan jasa-jasa serta kekayaan berharga lainnya serta untuk pembayaran hutang.

Secara kesimpulan, uang adalah suatu benda yang diterima secara umum oleh masyarakat untuk mengukur nilai, menukar, dan melakukan pembayaran atas pembelian barang dan jasa, dan pada waktu yang bersamaan bertindak sebagai alat penimbun kekayaan.

Dalam pengertian kontemporer, uang adalah benda-benda yang disetujui oleh masyarakat sebagai alat perantara untuk mengadakan tukar-menukar atau perdagangan dan sebagai standar nilai. Jadi uang adalah sarana dalam transaksi yang dilakukan dalam masyarakat baik untuk barang produksi maupun jasa, baik itu uang yang berasal dari emas, perak, tambaga, kulit, kayu, batu, besi, selama itu diterima masyarakat dan dianggap sebagai uang. ${ }^{5}$

Keberadaan uang ialah untuk menyediakan alternatif transaksi yang lebih mudah daripada barter yang lebih kompleks, tidak efisien, dan kurang cocok digunakan dalam sistem ekonomi modern karena membutuhkan orang yang memiliki keinginan yang sama untuk melakukan pertukaran dan juga kesulitan dalam penentuan nilai. Efisiensi yang didapatkan dengan menggunakan uang pada akhirnya akan mendorong perdagangan dan pembagian

\footnotetext{
${ }^{5}$ Muhammad Syarif Chaudry, Sistem Ekonomi Islam: Prinsip Dasar
}

(Fundamental of Islamic Economic System), terj, (Jakarta: Kencana, 2012), 
Macam-Macam Sistem Ekonomi

dan Kemerosotan Sistem Ekonomi Syariah

(ekonomi syariah di dalam dunia global)

tenaga kerja yang kemudian akan meningkatkan produktifitas dan kemakmuran.

Dalam ekonomi Islam, secara etimologi uang berasal dari kata al-naqdu, pengertiannya ada beberapa makna yaitu: al-naqdu berarti yang baik dari dirham, menggenggam dirham, membedakan dirham, dan al-naqdu juga berarti tunai. Selain itu, dalam konsep ekonomi Islam uang adalah milik masyarakat (money is goods public).

Uang menurut fuqaha tidak terbatas pada emas dan perak yang dicetak, tapi mencakup seluruh jenisnya dinar, dirham dan fulus. Ini mengisyaratkan bahwa uang adalah standar unit ukuran untuk nilai harga komoditas.

Pada intinya, uang adalah sesuatu yang dijadikan sebagai alat untuk melakukan transaksi pembayaran ekonomi di mana sesuatu yang dijadikan sebagai uang diterima, dipercaya dan disukai oleh masyarakat atau orang-orang yang melakukan transaksi ekonomi.

Agar masyarakat menyetujui penggunaan suatu benda sebagai uang, haruslah benda itu memenuhi kriteria sebagai berikut :

- Nilainya tidak mengalami perubahan dari waktu ke waktu

- Mudah di bawa-bawa

- Mudah di simpan tanpa mengurangi nilainya

- Tahan lama

- Jumlahnya terbatas (tidak berlebih-lebihan)

- Bendanya mempunyai mutu yang sama.

\section{Mekanisme Penggunaan Dinnar Sebagai Alat Transaksi}

Penggunaan emas sebagai alat transaksi perdagangan internasional dapat dilakukan melalui perjanjian pembayaran bilateral (bilateral payment arrangement) maupun perjanjian pembayaran multilateral (multilateral payment arrangement). Perjanjian pembayaran produk tersebut yang diperdagangkan akan melalui tahapan dan mekanisme yang melibatkan bank umum, bank sentral, dan custodian emas (penyimpan emas).

Ada empat tahapan yang dilalui dalam mekanisme transaksi perdagangan tersebut. Pertama, adanya perjanjian dagang antara importir dan eksportir yang berada di dua negara yang berbeda, dengan kejelasan kondisi barang dan jumlah barang yang akan 


\section{Amirudin}

ditransaksikan. Tentu saja, sesuai dengan syariat Islam, akad yang terjadi harus bebas dari unsur-unsur gharar, maysir, dan riba.

Kedua, setelah melakukan perjanjian dagang, kemudian pihak importir akan mengeluarkan letter of credit (LC) hal ini untuk melakukan pembayaran melalui bank yang sudah ditunjuknya. Selanjutnya, pihak eksportir akan menerima letter of credit (LC) dari bank tersebut. Ketiga, pihak bank yang ditunjuk oleh importir akan segera melakukan pembayaran kepada bank sentral dengan menggunakan mata uang lokal yang kemudian akan mengakumulasikan transaksi kedua negara dengan standar emas hingga masa kliring.

Keempat, setelah masa kliring selesai, bank sentral negara importir akan mentransfer emas senilai dengan transaksi perdagangan kedua negara kepada pihak custodian emas yang telah ditunjuk, untuk selanjutya diserahkan kepada bank sentral negara eksportir. Bank sentral negara eksportir ini selanjutnya akan melakukan pembayaran dalam mata uang lokal kepada bank yang telah ditunjuk oleh eksportir. Kemudian bank tersebut akan menyerahkannya kepada pihak eksportir. ${ }^{6}$

Mekanisme di atas memang jelas memiliki kelebihan dibandingkan dengan menggunakan mata uang asing lainnya. Kedua negara tidak akan mengalami fluktuasi nilai mata uang, yang seringkali menjadi hambatan dalam transaksi perdagangan. Bahkan, telah banyak fakta yang menunjukkan bahwa fluktuasi mata uang dapat mengakibatkan kehancuran perekonomian sebuah negara. Dengan mekanisme tersebut pula, stabilitas perekonomian akan lebih mudah dicapai, mengingat nilai emas yang relatif lebih stabil. Sehingga diharapkan, volume perdagangan antarnegara Islam dapat berkembang. Di sinilah dituntut peran OKI dan Islamic Development Bank (IDB) untuk dapat merumuskan konsep yang lebih matang terhadap gagasan ini. Keuntungan secara politis akan dirasakan oleh negara-negara Islam, karena nilai tawar yang dimilikinya terhadap Barat dan kekuatan lainnya menjadi semakin tinggi. Meskipun demikian, harus diakui bahwa mekanisme tersebut juga memiliki kelemahan-kelemahan. Kelemahan pertama, ketersedian emas yang

\footnotetext{
${ }^{6}$ http:/ / aang-kunaepi.blogspot.com/2013/07/mekanisme-penggunaan-emassebagai-alat.html
} 
Macam-Macam Sistem Ekonomi

dan Kemerosotan Sistem Ekonomi Syariah

(ekonomi syariah di dalam dunia global)

tidak merata di antara negara-negara Islam, sehingga dapat menimbulkan ketimpangan dan kesenjangan.

Kelemahan kedua, masih tingginya ketergantungan dunia Islam terhadap produk yang dihasilkan oleh negara-negara nonMuslim (baca: Barat), terutama terhadap produk-produk industri dengan teknologi tinggi. Kelemahan ketiga, nilai transaksi perdagangan yang masih sangat kecil sesama anggota OKI, yang menyebabkan signifikansi emas menjadi tidak terlalu substantif. Untuk itu, komitmen dan kesungguhan para pemimpin dunia Islam beserta pemerintahannya sangat dibutuhkan. Sebagai negara Muslim terbesar di dunia, sudah sepantasnya jika Indonesia diharapkan dapat memainkan peran yang lebih aktif, konstruktif, dan produktif. Indonesia memiliki peluang untuk mendorong terealisasinya blok perdagangan OKI, meskipun tantangan dan hambatannya tidak sedikit, terutama dari negara-negara Barat melalui kaki tangan mereka (IMF dan Bank Dunia).

Jika saja blok perdagangan ini dapat terwujud, maka bisa dibayangkan bahwa dunia Islam akan menjadi salah satu center of power yang strategis dan diperhitungkan, sehingga kondisi unipolar akan kembali berganti menjadi multipolar. ${ }^{7}$

Dalam pandangan al-Gazali uang adalah: "Nikmat Allah (barang) yang dipergunakan masyarakat sebagai mediasi atau alat untuk mendapatkan bermacam-macam kebutuhan hidupnya, yang secara subtansial tidak memiliki nilai apa-apa, tetapi sangat dibutuhkan manusia dalam upaya pemenuhan bermacam-macam kebutuhan mereka (sebagai alat tukar).

Karena itu al-Gazali mengibaratkan uang sebagai " cermin yang tidak mempunyai warna sendiri tapi mampu merefleksikan semua jenis warna." Dengan melihat kriteria tersebut diatas dapat dilihat bahwa dalam memberikan definisi uang, al-Gazali tidak hanya menekankan pada aspek fungsi. Definisi yang demikian lebih konprehensif dibandingkan dengan batasan-batasan yang dikemukakan oleh kebanyakan ekonomi konvensional. Sebab

\footnotetext{
${ }^{7}$ Adiwarman Karim. 2012. Ekonomi Makro Islam. Jakarta: Rajawali Pers.
} 


\section{Amirudin}

kebanyakan dari mereka mendefinisikan uang sebatas pada fungsifungsi yang melekat padanya.

Menurut Al-ghazali dan ibn Khaldun, definisi uang adalah apa yang digunakan manusia sebagai standar ukuran nilai harga, media transaksi pertukaran, dan media simpanan. ${ }^{8}$

\section{Faktor Merosotnya Sistem Ekonomi Syariah}

\section{a. Stagnasi para pemikir}

pada awal-awal mas islam, banyak kitab-kitab yang dikodifikasi oleh para ulama di antaranya tafsir, hadits, fiqh dan tentang ilmu pemikiran ekonomi syariah yang di elaborasi dengan ilmu pengetahuan. Namun di penghujung abad ke empat (4) hijjriyah, masalah perpecahan di internal ummat islam bergejolak sehingga mengalami perpecahan dan kubu masing-masing. Dan dengan hal tersebut menjadikan ummat islam yang awal kuat dan bersatu menjadi kafilah-kafilah yang kecil dan tidak kuat lagi. Dengan demikian tanpa di sadari menjadikan faktor runtuhnya kekhalifahan, dan semakin menambah kerapuhan ummat islam. Dan mekanisme sistem ekonomi setelah kejadiaan tersebut jauh dari nilai-nilai syariah. Dalam hal tersebut terjadi dekadensi moral terhadap masyarakat islam yang menjadikan ummat islam suka terhadap dunia dan suka terhadap jabatan. Distori kehidupan politik dan ekonomi ummat islam tersebut sangat berpengaruh terhadap pemikiran ulama, sehingga intelektuaslisasi saat itu tidak mampu untuk menjawab dinamika kehidupan ekonomi. Dan pada akhirnya tradisi pemikiran dan intelektualitas dalam mengakomodir problematika kehidupan masyarakat saat itu mengalami stagnasi. ${ }^{9}$

\section{b. Minimnya Kebutuhan}

Pada awal pertama kedatangan islam kebutuhan masyarakat akan pemikiran dan legalitas transaksi dalam sebuah kegiatan ekonomi belum begitu menggelora. Hal tersebut disebabkan oleh mekanisme kehidupan yang ada masih sangat sederhana dan belum banyak terjadi perkembangan-perkembangan pada sektor ekonomi

\footnotetext{
${ }^{8}$ httphs://www.kompasiana.com/taufikurrohman/uang-dalampersepektif-ekonomi-islam

${ }_{9}^{9}$ Zainudin.2008. hukum ekonomi syariah. Jakarta: Sinar Grafika.
} 
Macam-Macam Sistem Ekonomi

dan Kemerosotan Sistem Ekonomi Syariah

(ekonomi syariah di dalam dunia global)

yang menghasilkan barang dan jasa. Keadaaan tersebut juga di dukung oleh pelaku ekonomi yang masih sangat kental dengan nilai ketaqwaan dan kezuhudan serta konsistensi merkaa terhadap menjalankan nilai-nilai syariah dalm kehidupan mereka sehari-hari.10

\section{c. Perang Eksternal}

Di penghujung abad ke empat (4) hijjriah tersebut, penyakit wahn atau takut mati dan cinta dunia tanpa di sadari telah meracuni ummat islam saat itu. Masyarakat muslim cendrung mengandrungi kekuasaan dan kekayaan duniawi saja, sehingga hal tersebut menjadikan penyebab terpecahnya ummat islam menjadi bagian kecil dari komoditas masyarakat dunia. Masing-masing komunitas tersebut saling berselisih, bermusuhan dan berseturu. Keadaaan tersebut merupakan peluang emas bagi negara lain terutama negara eropa untuk melakuka ekspansi daerah jajahan mereka. Komunitas masyarakat muslim menjadikan sasaran tembak bagi kaum salib dalam memperoleh daerah jajahan meraka. Pada akhir abad lima (5) hijjriah kaum salib melakukan invasi militer dan ghal tersebut menghasilkan negara syam sebagai negara jajahan merekan saat itu. Dengan ada peperangan ini, menyebabkan terjadinya kehancuran dan kerusakan semua infrastruktur kehidupan.

Pada pertengahan abad ketujuh (7) hijjriah,masyarkat muslim mengalami penjajahan di segala aspek kehidupan baik sosial, politik, budaya, pemikiran dan ekonomi.hal tersebut merupakan sebuah penghalang yang sangat fundamental bagi pengembangan pemikiran islam dan kehidupan ekonomi islam.perkembangan teknologi dan perindrustrian di Eropa dan Amerika menstimulasi terhadap perkembangan pemahaman ekonomi serta sistem dan mekanisme yang di terapkan mereka pada saat itu. Perkembangan tersebut menyebabkan kemunduran terhadap perekonomian dan teknologibagi masyarakat muslim.perkembangan perekonomian dan teknologibagi masyarakat muslim menjadi terhegemoni dengan Negara Barat. Akhirnya negara-negara muslim menjadi negara dunia ketiga. ${ }^{11}$

\footnotetext{
${ }^{10}$ Azwar k. Adiwarman. 2006. Sejarah pemikiran ekonomi islam. Jakarta: PT Raja Grafindo Persada.

${ }^{11}$ Marthon S. Said. 2007 sejarah pemikiran ekonomi islam .jakarta: PT Raja Grafindo Persada
} 


\section{Amirudin}

Menurut Umar Chapta seperti yang dikutip Merza Gamal kemunduran ummat islam di mulai sejak abad ke duabelas (12) yang di tandai dengan kemerosotan moralitas, hilangnya dinamika dalam islam setelah munculnya dogmatisme dan kekakuan berpikir, kemunduran dalam segi aktivitas intelektual dan segi keilmuan, pemberontakan lokal dan perpecahan di antara ummat islam itu sendiri, peperangan dan serangan dari pihak luar, terciptanya ketidak seimbangan keuangan dan kehilangan rasa aman terhadapa kehidupan dan kekayaan, dan faktor-faktor yang mencapai puncaknya pada abad keenam belas(16), yaitu pada masa dinasti Mamluk Ciscasiyah yang penuh korupsi, sehingga mempercepat proses kemunduran tersebut.

Kemajuan dan kemunduran yang di alami oleh ummat islam itu bukan seperti sebuah garis lurus, akan tetapi naik turun dan berlangsung ber abad- abad lamanya. Berbagai macam upaya dan usaha yang telah di lakukan oleh ummat islam untik menghentikan kemunduran itu, namun sebab karena utama atau vital tetap ada, maka kemerosotan tetap berlangsung sampai saat ini. Faktor utama untuk menghindari hal tersebut adalah kembali kepada ajaran islam yang sesungguhnya berorientasi terhadap falah oriented, yaitu menuju kemakmuran di dunia dan kebahagiaan di akhirat.

\section{Penutup}

Setelah kita mengetahui sedikit banyak ekonomi macammacam sistem ekenomi syariah yang telah kita bahas di atas. Seyogyanya kita bisa sedikit mengamalkan hal-hal yang bisa di ambil manfaatnya dari sebuah sistem ekonomi syariah yang telah menjadi sebuah sistem dalm kehidupan sehari-hari. Dan pelak dari hal ini adalah yang menjadi pembhasan di atas sebuah alat tukar yang menjadikan tolak ukur sebuah sistem ekonomi di dunia. Sebagai masyarakat muslim tentunya yang menjadi patokan buat kita adalah al-quran dan hadist sebangai pedoman hidup. Dan begitu pula dengan sistem ekonomi syariah yang menjadikankan alat ukurnya adalah emas, perak dan perunggu. Namun sejalan berkembag zaman dan tak luput dari peran para pakar ekonomi dunia yang yang berbeda agama, hal tersebut di selewengkan untuk menjadikan sistem ekonomi dunia ini menjadi kapitalis atau konvensional. 
Macam-Macam Sistem Ekonomi

dan Kemerosotan Sistem Ekonomi Syariah

(ekonomi syariah di dalam dunia global)

Maka disini penulis memberikan sedikit pendapat tentang keunggulan menggunkan nilai tukar menggunakan emas. Walaupun hal tersebut telah ditetapkan oleh Kurs Mata Uang dunia. Yang terpenting adalah sistem ekonomi apapun yang di gunakan pasti ada kelebihan dan kekurangannya oleh hal tersebut tetap di jaga apapun yang menjadi nilai tukar uang bagi kita dalam kehidupan sehari-hari. Dan seyogyanya ummat islam pada saat ini harus mewujudkan keislamannya dalam segala aspek kehidupan sehari-hari termasuk kehidupan ekonominya. Karena sesungguhnya, ummat islam telah memiliki sistem ekonomi tersendiri dimana panduan utamanya adalah al-quran dan hadist yang menuju kebahagiaan dunia sampai ke akhirat kelak. 
Amirudin

\section{Daftar Pustaka}

Azwar k. Adiwarman. 2006. Sejarah pemikiran ekonomi islam. Jakarta: PT Raja Grafindo Persada

Adiwarman Karim. 2012. Ekonomi Makro Islam. Jakarta: Rajawali Pers. https://www.eramuslim.com

http://aang-kunaepi.blogspot.com/2013/07/mekanisme-penggunaanemas-sebagai-alat.html

httphs://www.kompasiana.com/taufikurrohman/uang-dalampersepektif-ekonomi-islam

Muhammad Syarif Chaudry, Sistem Ekonomi Islam: Prinsip Dasar (Fundamental of Islamic Economic System), terj, (Jakarta: Kencana, 2012),

Marthon S. Said. 2007 sejarah pemikiran ekonomi islam .jakarta: PT Raja Grafindo Persada

Tulus T.H Tambunan, 2009. Perekonomian Indonesia. Bogor: Galia Indonesia

Winardi, 1987 Pengantar Ekonomi Moneter, Buku-1, Bandung: Tarsito.

Zainudin.2008. hukum ekonomi syariah. Jakarta: Sinar Grafika. 